\title{
COASTAL ZONES - SEISMIC VULNERABILITY AN ANALYSIS FROM EAST COAST OF INDIA
}

\author{
B. L. Narasayya ${ }^{1}$ \\ ${ }^{I}$ Rtd. Dy. Director General G.S.I
}

\begin{abstract}
The paper briefly attempts at a conceptual approach on the reported events of moderate seismic activity from parts of East Coast of India originating from the shallow depths of sea floor in a short span of less than two decades. As a passive continental margin, it is assuring to feel a stable condition for the East Coast. But its Geotectonic critical position in the Bay with Andaman Islands architecture on the east and further east the Indonesian Islands and experience of 2004 Tsunami of devastating nature hitting the Southern East Coast necessitates that the geo technical frame has to be critically studied from the point of view of Active Tectonics and as a mitigation measure appropriate building codes have to be implemented in seismic designs.
\end{abstract}

Keywords: seismic activity, geotectonic critical position, Tsunami, mitigation

\section{INTRODUCTION}

Asia Pacific bears the brunt of many natural hazards. About five million deaths took place in the $20^{\text {th }}$ century alone. The human losses due to $26^{\text {th }}$ Dec. 2004 Tsunami are reported over lakhs. One estimate is that about $60 \%$ of the area in India is prone to earthquakes which frequent different high risk zones like the Himalayan belt, the Eastern arc as well as Continental interiors. The concept of the so called "Shield area" has almost disappeared.

\section{HAZARDS - A GEOPERSPECTIVE}

The Geosphere comprising Lithosphere, Hydrosphere, Atmosphere and Biosphere continuously undergoes interactions among the different process variables resulting in their manifestations such as earthquakes, volcanisms etc. Cyclone, floods are entirely driven by atmospheric hydrospheric regimes through the mechanism of solar energy and forecasting is possible with the designated process parameters. Earthquakes originate at the depths either on land or on ocean beds, occasionally with devastating Tsunamis affecting the contiguous landmasses. There exists prediction component available for Tsunamis on the data base and high-end technology. The Earth's evolution in time and space from the Achaean times to the recent must have witnessed dramatic and Catastrophic events such as episodes of volcanism, meteoric bombardment with tectonic instability. The records of deformation, earthquakes are often obliterated or sparsely preserved in forms further to be decoded. The palaeo earthquake records are dated through signatures in the quaternary. Historical records (post human settlements and civilizations) and logging gave us the some idea of the occurrences of the earthquakes spread over different parts of the globe even during the pre-instrumental days. With the advent of a "Seismograph", documented data had been available notably from countries like China and later in Japan in the year 79 A.D. with historical geological events of volcanism at Pompeii and earthquakes in Italy, remained a landmark for the strengthening of seismic and related studies in critical affected areas. The available data over the last two centuries only is spread over unevenly from different parts of the world and often with diversity in content of scientific parameters. But devastation in terms of losses of lives and property is the biggest casualty to human kind caused by earthquakes.

\section{ANCIENT AND MIDIVIAL WORK}

In India also ancient science has reached a very high landmark even on the studies pertaining to earthquakes as documented in the details of "Brihat Samihita" by VARAHA MIHIRA as early as $6^{\text {th }}$ century A.D. giving description to the areas likely to be affected and people in those kingdoms along with the type of earthquakes as a classification. Earthquakes were less a boon and more a bane. Study of earthquakes provided us the knowledge of earth's interior. Credit goes to old hams work. The doors of seismology were opened. Earlier renowned investigators studied earthquakes and their effects. Prof. Celsius studied in Gulf of Bothinia. Darwin studied on board HMS Beagle in the areas of South America coast and Moho from Balkans. An astronomer Schmidt studied earthquakes in Rhine graben and in fact coined the term epiccentre. Earlier phase of studies had a focus on surface affects, modifications and even related rupture details to seismic phenomena. The earliest catalogue of earthquakes and a geological documentation originated in India. Even though earthquakes were part of tectonic and thermal regimes right from early crustal evolution, their documentation was only a few centuries old after the advent of seismograph. 


\section{SOME SIGNIFICANT MODERN CONTRIBUTIONS}

The tectonic architecture of peninsular and extra peninsular India has been worked out by many investigators ( Krishnan (1982), Grady (1976), Mahadevan (1994), Mishra (2006), Ravishanker (1995), Balakrishnan et.al., (2009) and Valdiya(1976). In furtherance combining seismicity and tectonics, emphasis has been laid on seismotectonics of the entire regions. ( Chandra(1977), GSI (2000) documenting the historic and cultural evidences, catalogues of earthquakes had been prepared as early as nineteenth century (Oldham 1883). With more and more data historical seismicity has been given a thrust resulting in a workable data base for further processing. Along with data from organizations like GSI, IMD. Many contributors made significant advances. (Rao and Rao 1984) In addition to individual earthquakes being well studied and published. Earthquakes in specific Geotectonic environments like shield areas had received attention. (Gupta nd Gupta 2003). Himalayan Seismogenesis and Plate Tectonic models of Inida together with eastern and north-western neighbors has remained as focus of global attention along with assessment of seismic Hazard.. (Bilham et.al., 2001, Khattri et.al., 1984, Ravikumar and Bhatia, 1999)

Thus, Seismic investigations have enabled newer insights into the understanding of the earth's internal layers and their compositions, heterogeneity in the material media, presence of liquid phases in the core etc. Earthquake studies began from Geological Survey of India 1819 Rann of Kutch, 1892 Baluchistan earthquake, 1897 Assam earthquake and recorded significant observations such as abrupt modifications of ground surface. Oldham (1898) is one of the earliest to recognize different Geological expressions, ground ruptures etc. established that earthquakes are related to faults. It may be emphasized that surface expressions of earthquake faults can be more potentially utilized to have a deeper insight the dynamics. However, there has been a shift from the geological base of study more towards seismogram analysis progressively and qualification in Hazard assessment studies.

\section{TECTONICS CONFIGURATION:}

AN

\section{OUTLINE}

The advent of Plate Tectonics has brought out many unified facts regarding the distribution and trends of earthquake zones globally. Plate boundaries are imaged by earthquake epicenters. Briefly it may be stated that India's tectonic configuration comprise the following tectonomorphic provinces .(Krishnan 1982, Balakrishnan 2009, Chandra 1977, Mahadevan 1994)

1. Himalayan belt and the Tertiary mobile belts on the east and west.

2. Indo-Gangetic fore deep.

3. Peninsular shield (a mosaic of Archean nuclei with peripheral proterozoic mobile belts.

4. Intra-continental basins.

5. Passive continental margins on east and west.
The Geotectonic set up of India is further characterised by Andaman Nicobar Islands, 85 degrees - 90 degrees E ridges on the east, Lakshadweep chagos, sea mounts and ridges on the west.(Ravikumar and Bhatia 1999) . Further on the east, countries like Indonesia, Malaysia, Japan have been frequented by devastating earthquakes and Tsunamis. India's adjoining tectonic regimes on the east are far more complex tectonically.

\section{2004 TSUNAMI}

A devastating earthquake on the west coast of Sumatra (Dec. $26^{\text {th }} 2004$ ) generated Tsunami hitting the Indian and Sri Lankan coasts. Tsunami waves transgressed over a lateral distance of $300-500 \mathrm{~m}$ with a run-up elevation of a maximum 5 meters in a few segments. The coast witnessed emergence of new surfaces in the beach front, erosion of spits, breaching along the coastline etc.

There had been reports of Tsunami and related hazards following earthquakes in Indonesia and other island groups on west of Indonesia. While Tsunamis are secondary effects (though not in devastation) of earthquakes, as also landslides, earthquakes are also secondary or consequent upon volcanism at places like Western U.S. Yellow stone area which are by and large non-tectonic in origin.

\section{COASTAL ZONE - CONTINENTAL MARGIN}

A coast is a geomorphic expression and which more or less marks the outer landward limit of the oceans or seas or the outer seaward limit of the land and is not a defined or marked line. It oscillates between the highest high water tide mark and lowest low water tide mark during the daily cycles. Within a longer geological span, there are many oscillations of sea level on a much wider zone, marks of transgressions and regression cycles which are registered through geological indicies. In the context of plate tectonics with ocean basins and continents as two marked geomorphic expressions, a continental margin marks the geological boundary between the two domains. Further the continental margins as tectonic domains, may be passive type (Atlantic) or active type (Pacific). The passive margins and ocean basins with, shelf, slope, rise etc. are considered to be largely aseismic or stable. Maximum seismic energy is released at the Pacific type active margins with subduction related earthquakes of very high magnitudes. Active margins are characterized by mountains, trenches and active volcanoes with extreme topographic variations.

\section{PENINSULAR INDIA \& EAST COAST}

The Geology of Peninsular India mainly comprises Precambrian assemblages with Jurassic to Quaternary sedimentary rocks and volcanics of Cretaceous-Eocene. The on-shore and offshore regions of East coast are mainly younger sequences with prospects of hydrocarbons. The Coastal areas have undergone repeated cycles of sea level changes during Quaternary. Prominent geomorphic elements along the East Coast are Ganges, Brahmaputra delta, Mahanadi, Godavari, Krishna, Penna and Cauvery deltas. 
(Fig.1) The Coastal risk along Peninsular Coast has been worked out prior to the advent of cyclone of 2004 (Banerjee et.at., 2001)

Later Inter-minittent seismic activity along parts of East coast is reported around the following places from reports during the period.

$\begin{array}{ll}1 & \text { Off. Odisha coast, May, } 2014 . \\ 2 & \text { Off. Visakhapatnam, Jan., } 1996 . \\ 3 & \text { Off. Pondicherry, Dec., } 2001 .\end{array}$

The shallow depth origin and possible rejuvenation of faults are broadly surmised in the above examples. Further general observations along East Coast are as follows either onshore/off-shore. Evidences of uplift and subsidence are reported. Further there are evidences of disturbances in the top layers of sediments along parts of East Coast by way of displacements in the layers as seen in the sub-bottom profiles. There are also rise-like structures below the top reflector. Presence of hot springs and field evidence showing displacement on a small scale are noticeable on ground. There are evidences of coarse sized sand and pebbly rich aggregates of sediments on the deep sea floor at around $2500 \mathrm{~m}$ depth beyond slope as observed at Off. Pennar. Such exotic sediments are possibly seisomogenic turbidites (GSI unpublished sea bed survey reports 1983-2000). Thus it is prudent to infer seismic activity, neotectonism and upper continental crust along East Coast at places.

\section{EARTHQUAKES PROCESS VARIABLES:}

By and large most of the earthquakes originate in the lithosphere. The different levels of crustal layers have geometrical disposition and possible seismogenic horizons. There is compositional and mineralogical change from upper crust towards more mafic-rich and then more magesian rich. Pressures, temperatures and fluids affect the degree of stability of the minerals and the rocks. The role of pore fluids and fluid pressures in weakening the rock is broadly well known but less experimentally documented. Failure of materials, nucleation and nature of the seismogenic crust are thus most valuable data base. The low velocity zones are of value in critical sectors of seismic source areas and seisomogenically vulnerable areas and in revealing the nature of material through high resolution data on density inferred through accurate velocities.

\section{NEOTECTONICS -EARTHQUAKES}

On a mega-scale the fragmentaed Indian Shield and recent earthquakes are considered in conjunction as important. (Ravishenkar 1995). Further uplift during neogene and rejuvenation had been recognized as field evidences in the younger geological column (Radhakrishna 1993)

A study of recent deformation of the crust geologically of quaternary (and also Pleistocene and even Pliocene) forms the main theme of neotectonics. Active tectonics are those tectonic movements that are expected to occur within a future time span of concern to society. Any fault that moved in the last say 35,000 years (or 10,000 years) is considered as active fault. Active Tectonics involves dynamic process operating in the present day regimes. Sometimes there exists a correlation between active faults and active volcanoes. Combining active tectonics and records of reported seismicity new generation maps or models of seismotectonics could be framed combining the inputs of Geology and Geophysics and Seismic Microzonation maps. Existing seismic zonation maps have to be accelerated to higher degree.

Pertaining to the East Coasts, for the last 200 years there are no authentic historical records of seismicity of such reported events or causalities. The extension of the continental crust is well postulated together with active faults or those rejuvenated along pre-existing faults. However, despite moderate seismic activity reported along parts of East Coast from the off shore there is no major seismic activity in the area, so far, from these parts of passive margin. Prudently such signs have to be read in holistic set up. The complex tectonic elements on the East including the Burmese-arc, Andaman archipelago, The Indonesian archipelago have diverse spreading and converging elements and result in a complicated dynamics. Seismic stability cannot be assumed and preparedness is needed especially in view of 2004 Tsunami of Sumatra Earthquake. $-9-$

\section{FUTURE LOOK}

Against the immense data available in respect of earthquakes, their science an attempt towards progresses of at least the vulnerability criteria could be a worthwhile endeavor with the aid of all modern tools of geology, geomorphology, geodesy, geo physics- geo chemistry and remote sensing. As the only visible marking available is though active faults and neotectonics for generating new class of seismic hazardzonation maps, on priority of know source zones and historical seismicity criteria, with emphasis on the geodynamic factors. Though not the time and place for forecasting the search for active faults through available criteria and search for hidden faults through geology centered techniques along with geophysics/ geo chemistry analogies to search for hidden deposits should become a programme of national endeavor for many reputed national organizations and their teams. It is stressed that strict implementation of building codes as per Bureau of standards and appropriate seismic designs are adhered to in future in all the vulnerable areas and as per zones indicated.

\section{CONCLUSION}

1. There has been a view that widely prevalent shield area is largely considered to be stable. However, this point of view has changed over as there are events of both high magnitude seismicity dominantly in the Himalayan belt and Eastern belt and moderate events or difuse seismicity in the Central and Southern parts of the country. The Coastal margins on both East and West are specific with their respective features. 
2. The Eastern Coastal areas all along the peninsula also witnessed moderate events of seismic nature as evidenced by the recent reports from Off. Odisha Coast, Off. Visakhapatnam and Off. Pondicherry which are pointers towards Coastal domains as well the adjoining margin areas. However, the tectonogeomorphic set up changes form North to South.

3. In view of accelerated developmental programs and even nuclear facilities likely along the east coast in future mitigation measures such as earthquake resistant designs need to be an integral part of design and implementation.

4. Even large reservoirs need to be analyzed from seismic vulnerability point of view as reservoirinduced seismicity is also reported at places like Koyana.

5. Microzonation needs to be taken in such sectors as measures of Prognosis, Sub-surface geophysical analysis and holistic surface geological criteria such as active faults are visibly significant clues. These can find place in new programmes to be pursued.

6. In view of mounting population, urbanization the need for developmental facilities of high values, prevalence of non-engineered structures as a rule, even a minor or modulate nature in Coastal corridors stands as a high risk factor at least a zone of around $50 \mathrm{kms}$. Building codes, thus are a safe need with designs of earthquakes and cyclone resistant modules.

\section{ACKNOWLEDGEMENTS}

The author expresses his gratitude to GSI and the team members of GSI who had been associated at various stages in the data collection, processing and interpretation in various projects on board the Research Vessels in Cruises. The opinions expressed are general and those of the author alone from efforts in synthesizing the unpublished data.

\section{REFERENCES:}

[1] Balakrishnan, T.S., P. Unnikrishnan, AVS Murthy (2009) The Tectonic Map of India and Contiguous areas Journal. Geological Society of India. Vol. 74, Aug-2009. PP. 158-170.

[2] Banerjee. P.K., G.G. Vaz., B.J. Sengupta, A. Bagchi (2001)A qualitative assessment of seismic risk along the peninsular coast of India, South of 19 degrees North.Journal of Geodynamics vol. 31(5) PP. 481498

[3] Bilham. R., Gaur. V.K. and Monar.P., 2001 Himalayan seismic Hazard, Science 293, PP. 14421444.

[4] Chandra.U(1977) Earthquakes of Peinsular India - a seismotectonic study, Bull- Seismol. Society Vol. 67, PP. 1387-1413

[5] Grady. S.A. (1971) Deep main faults in South Journal Geological Society of India 12, PP. 56-62

[6] GSI (2000) Seismo tectonic Atlas of India and its environs September 2000, 42 sheets
[7] H.K. Gupta and G.D. Gupta (Ed.) (2003) Earthquakes studies in Peninsular India Memoir 54, Geoligical Society of India, Since 1993, PP.254

[8] Khattri K.N., A.M. Rogers, D.M. Perkins and S.T. Algermissen (1984). A Seismic hazard map of India and adjacent areas. Tectonophysics Elsevier Science Publishers 108, PP.93-134

[9] Krishnan. MS (1982 Sixth edition) The Geology of India and Burma CB S Publishers, PP.536

[10] Mahadevan T (1994) Deep Continental Structure of India: A Review Mem.28 Geological Society of India, Bangalore.

[11] Mishra. D.C. (2006) Building blocs and Crustal architecture of Indian Peninsular shield: Cratons and Fold belts and their interaction based on geophysical data integrated with geological information. Journal Geological Society of India, Vol. 68, December2006. PP.1037-1057

[12] Oldham T(1883) A Catalogue of Indian Earthquakes from the earliest times of the end of 1869 AD. Mem. Geological Survey of India Mem. Geological Survey of India XIX, Part-3. PP. 163-251

[13] Oldham, R.D.(1898) A Note on the Allahbund in Nonthwest of Rann of Kutch Geological Survey of India, Mem. 28, PP. 27-30

[14] Radhakrishna. B>P. (1993) Neogene uplift and Geomorphic rejuvenation of Indian Peninsular Curr.Sci.64, P.P.787-793

[15] Rao B.R., and Rao. P.S. (1984) Historical Seismicity of Peninsular India Ball. Scism. Society. Am.,74(6) PP.2519-2533

[16] Ravikumar M. and S.C. Bhatia (1997) A New Seismic Hazard map for the Indian plate region under the global seismic hazard assessment programme Curr. Sci. Vol.77, No.3 PP.447-453

[17] Ravishanker (1995) Fragmented Indian Shield and recent earthquakes Rec. Geological Survey of India 27. PP.41-48

[18] Valdiya. K.S.(1976) Himalayan Transverse faults and folds and their parallelism with Subsurface structures of North Indian Plains Tectonophysics, 32. PP. 358-386 